\title{
The "Two Camels" of Koussa: A Massive Ferrous Meteorite in Mayo Binka (North-West Region in Cameroon)
}

\author{
Bernard Njom¹, Aurélien Temenou Tiolo' ${ }^{1}$, Jacques Bertrand Onana ${ }^{1}$, \\ Yanick Nyobe Bayi ${ }^{1}$, Augustin Patrice Moussango Ibohn'2, \\ Simon Pierre Mbog Bassong ${ }^{3}$, Michel Guy Awana Ateba ${ }^{1}$, \\ Madi Boukar', Thierry Abou'ou Ango', Jean Claude Ngoute', \\ Belle Koumedjalla1, Georges Emmanuel Ekodeck ${ }^{1}$ \\ ${ }^{1}$ Faculté des Sciences, Université de Yaoundé I, Yaoundé, Cameroun \\ ${ }^{2}$ Institut de Recherches Géologiques et Minières (I.R.G.M), Yaoundé, Cameroun \\ ${ }^{3}$ Musée National Cameroun, Yaoundé, Cameroun \\ Email: njomb@yahoo.fr
}

Received 13 July 2015; accepted 22 September 2015; published 25 September 2015

Copyright (C) 2015 by authors and Scientific Research Publishing Inc.

This work is licensed under the Creative Commons Attribution International License (CC BY). http://creativecommons.org/licenses/by/4.0/

c) (7) Open Access

\begin{abstract}
At Koussa in Mayo Binka, a hundred kilometers northeasterly from the town of Bamenda, the Capital of the North-West Region in Cameroon, an enormous block of native iron of several tons in mass is found. The observation of the Southern view of this block let anyone see a configuration which surprisingly recalls two camels in an attitude that these animals generally adopt when they are at rest. This strong resemblance with the attitude of these animals in rest has led the local populations in identifying this enormous metallic block with the name of "the two camels' couple" or simply stills "the two camels". The test conducted with the acid let the Neumann figures be revealed the Neumann figures which confirm this metallic block as being a ferrous meteorite or a siderite of the Hexaedrites class.
\end{abstract}

Keywords

Koussa, Mayo Binka, Bamenda, Cameroon, Neumann Figures, PDF's, Hoba, Hexaedrites, BIF

\section{Description of the "Two Camels" of Koussa (Plate II)}

The block of native iron of Koussa has an East-West general orientation along which it lengthens. Three views of this block of native iron are presented here: the Southern, the Northern, and the Western sights.

How to cite this paper: Njom, B., Tiolo, A.T., Onana, J.B., Bayi, Y.N., Ibohn, A.P.M., Bassong, S.P.M., Ateba, M.G.A., Boukar, M., Ango, T.A., Ngoute, J.C., Koumedjalla, B. and Ekodeck, G.E. (2015) The "Two Camels" of Koussa: A Massive Ferrous Meteorite in Mayo Binka (North-West Region in Cameroon). Open Journal of Geology, 5, 649-654.

http://dx.doi.org/10.4236/ojg.2015.59057 


\subsection{The Southern View (Plate II)}

It is by far the view which offers to the observation, invaluable block details in connection with arguments making it possible to go up the trajectory of the long flight of this block from space to Koussa. The regmaglytes that one sees there are giant, of inhabitual dimensions; three of these regmaglytes of sub-metric to metric size are prominent and seem to carve this Southern face of the metallic block; the largest and deepest of these regmaglytes is of $1.5 \mathrm{~m}$ in diametre for a depth beyond the metre. This deepest regmaglyte from this view is centrally situated on the metallic block. The second regmaglyte in the view disunites the "spinal columns" of the two "animals"; and the third and fourth regmaglytes are affecting the right "shoulders" of both "animals". The metallic block is stretched on close to $6 \mathrm{~m}$ in its East-West orientation for a height of more than $3 \mathrm{~m}$. These dimensions are actually the first or initial indications since the metallic block is deeply buried. The geophysics approach relating to the measurement of the resistivity's values around the metallic block revealed its prolongation back towards the West on more than $3 \mathrm{~m}$ distance, and in depth. In spite of the rust marker of the time already passed at Koussa, traces of castings pointing out a fusion crust are still visible inside the receptacles which constitute these regmaglytes. A more or less deep central furrow braided in height seems to connect these regmaglytes the ones to the others.

\subsection{The Northern View}

This face is marked by the prevalence of the protuberance corresponding to the gigantic hollow of the major regmaglyte of the opposite face.

\subsection{The Eastern View}

It is allowed or obtained from the western sight; this view offers to the observation, the heads of both "animals" vertically and horizontally shifted. The head ahead is lightly presented in profile because of its slight rotation towards the South.

The fusion crust and the central furrow give certainly an account of fluids dynamics in relation with the successive thermal states along the final incidental trajectory of this meteorite.

\section{Chemical Composition}

Chemical analyses performed in Ireland (OMAC Laboratories) gave the results below (\%):

\begin{tabular}{ccccccccccccc}
\hline $\mathrm{SiO}_{2}$ & $\mathrm{Al}_{2} \mathrm{O}_{3}$ & $\mathrm{Fe}_{2} \mathrm{O}_{3}$ & $\mathrm{CaO}$ & $\mathrm{MgO}$ & $\mathrm{Na}_{2} \mathrm{O}$ & $\mathrm{K}_{2} \mathrm{O}$ & $\mathrm{Cr}_{2} \mathrm{O}_{3}$ & $\mathrm{TiO}_{2}$ & $\mathrm{MnO}$ & $\mathrm{P}_{2} \mathrm{O}_{5}$ & $\mathrm{SrO}$ & $\mathrm{BaO}$ \\
\hline 1.08 & 0.47 & 87.7 & 0.03 & 0.13 & $<0.01$ & 0.05 & 0.02 & 0.13 & 0.04 & 0.17 & $<0.01$ & $<0.01$ \\
\hline
\end{tabular}

ppm: C: 0.04; S: 0.17; Ni: 19; Ir: <0.001; Os: $<0.01$.

The Fe high content (87.7\%) relates to the former initial homogeneity in composition of the "two camels" the actual composition of which reveals some chemical pollution namely in silica, surely from the proximal environment made of Precambrian granites irregularly caped with tertiary volcanites. Fe could have combined with $\mathrm{S}$ in the Troïlite mineral (FeS); presence of $\mathrm{Ni}(19 \mathrm{ppm})$ is an indication of the Fe-Ni alloy from a former initial liquid very low in Ni content. PGE members are present of which Ir with a prevalent concentration 20 times higher than that of the terrestrial Crust [1] [2]!

\section{The Neumann Figures}

Native iron is distinguished from iron associated with the natural phenomena inherent to sedimentation or magmatism which are endogenous phenomena of our planet, by more increased density ( $\geq 4)$ but especially by the specific reaction which it causes during the test to the acid. Two cases of figure are then observed: Windmannstäten figures which reveal variations in chemical composition (relative contents between taenite and kamacite) of the initial metallic liquid with more than 5\% of Nickel content during its crystallization; this crystallization gives place to Siderites of the Octaedrites class. The Neumann bands markers of the successive shocks undergone by parents' bodies during their phase of differentiation, shocks which are at the origin of the poly- 
granulation or the brecciaton. These Neumann bands and this polygranulation characterize Siderites too; but those of the Hexaedrites class [3]-[6].

The acid tests were performed on a sample taken away from the "two camels" and on another block of native iron found around the town of Sangmélima in the Southern Region of Cameroon. The results of these tests are those appearing in various images of the above plate (Plate I): the block of native iron of Sangmélima after the test undoubtedly reveals a polygranulation with a variation of colour in connection with a light variation in the chemical composition of these grains. Geometrical arrangement appears unspecified or random what reinforces a mechanism of brecciation (a and b images). On the "two camels" sample, the acid shows rectilinear lines defining intersecting bands in angles nearly equal to the right angle; the generated geometrical figures are those of the cubic class $\{001\}$ since one recognizes in the images, squares which are geometrical figures drawn by preferential casting of iron in thin straps due to the energy of the crossing shock wave, which highlighted the isometric structure specific to metals: these are the Neumann bands (images c, d, e, f, g) [3]-[6].

The acid tests either on the "two camels" sample or on the native iron block of Sangmélima, allow the strong and undeniable conclusions: the polygranulation and the Neumann bands both related to the shock effects, reveal the intrinsic meteoritic nature of Siderites, that of the Hexaedrites class.

\section{Discussion}

\subsection{Questions Relative to the Native Iron Presence onto the Earth Surface}

Native iron generally poses a problem; that of its origin or its source when found on the Earth surface. What is indicated as Itabirites or BIF is a set or a mixture between the crystals of magnetite and sand [7] [8]; these sedimentary formations of old age (Precambrian) characterize from the paleogeographic consideration, a sufficiently dry climatic context so that evaporation exceeds the contributions by precipitations. Such a context points out that of the deserts such as one can observe them today on Earth, with their extreme scarcity of the rains. Iron saturates within the various ponds and other pools, and starts to precipitate at the bottom while mixing with sand.

Knowing that the sand dune is the major palaeogeographic marker of a desert, the debate on the possible presence of Itabirites in our country deserves to be opened: nowhere in the geographical sectors where these "Itabirites" in our country or elsewhere in the sub-region are announced, nobody still provided the least proof of
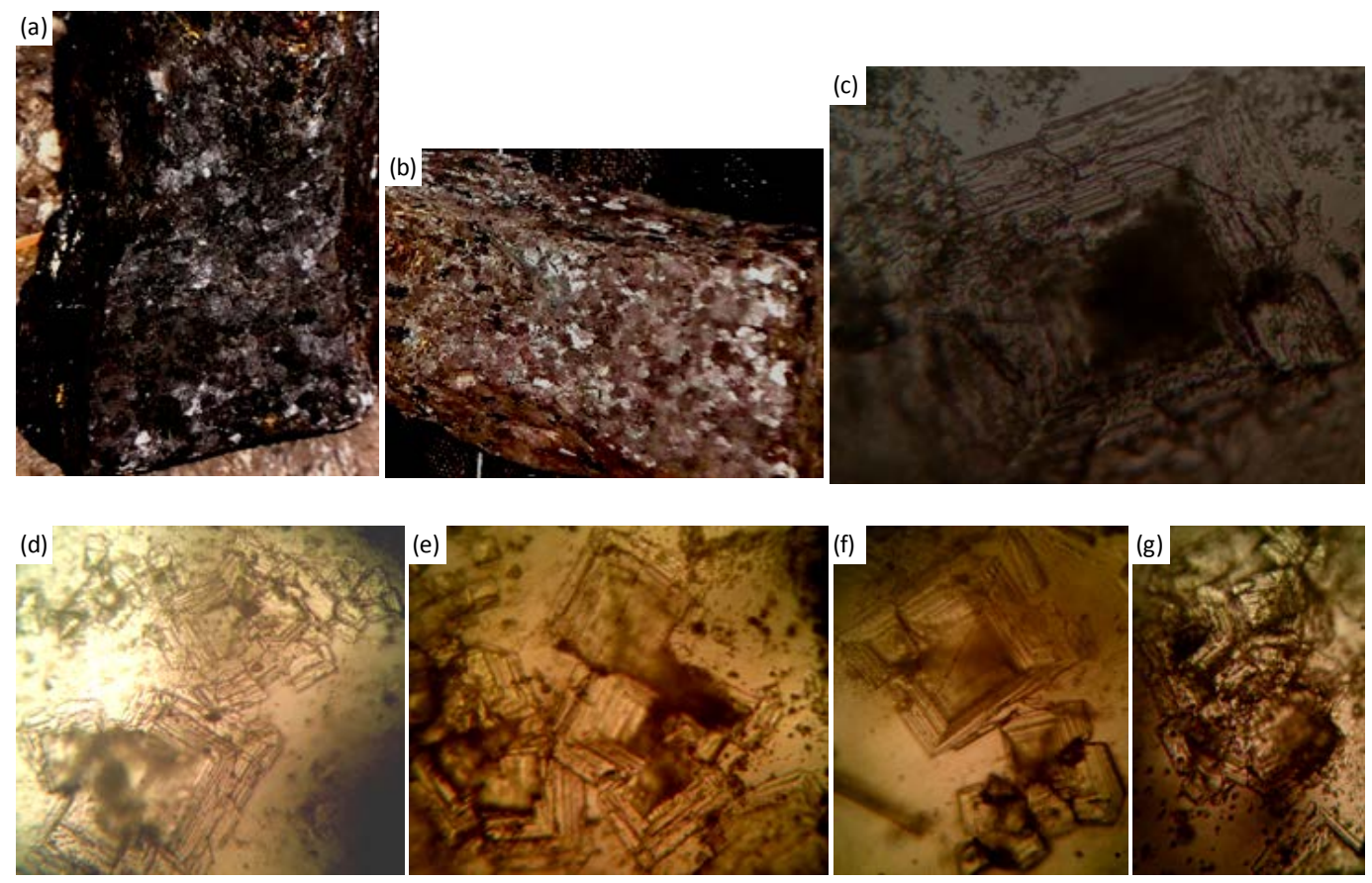

Plate I. (a) (b) Brecciated texture of a native iron block from Sangmelima revealed after the test acid; (c)-(g) Brecciated texture and Neumann figures from the "two camels" of Koussa confirming a meteoritic nature of the Hexaedrites class. 
a presence of the fossil dunes having to validate a paleogeographic context of a desert. On the other hand the hydrographic networks of multiple and concentric rings layout in Cameroon for example, which reveal immense multi-rings basins such that of Dja or that of Great Mbam abounding in much water, the strong recurrence of breccias on the whole of the Gulf of Guinea area, all of these parameters being either geomorphological or lithological, characterize the impact craters and thus the phenomenon of meteoritic impact [4]-[6], [9]-[16]. The meteoritic nature of the "two camels" in Mayo Binka and that of the block of native iron of Sangmélima revealed through the test with the acid fully confirm a phenomenon of meteoritic impact on a large scale in the Gulf of Guinea. The iron found in our country and elsewhere in the sub-region of Central Africa, is thus more meteoritic than sedimentary. And the emblematical "couple of the two camels" of Mayo Binka with its mass and size, is the concrete and undeniable proof of a powerful bombardment of our sub-region by metallic hyperveloce bolides coming from space; that is the mechanism of installation of all the iron ores in central Africa.

\subsection{The "Two Camels": The Largest Meteorite in the World}

The stretched configuration of the meteorite of Mayo Binka along the East-West direction, gives him in space, a general morphology which is that of a triaxial ellipsoid directed along its major axis; this major axis is of $6 \mathrm{~m}$ length. The intermediate axis corresponds to the height of the meteorite either $3 \mathrm{~m}$, and the minor axis coincides with the depth of the largest regmaglyte dug at the centre of the meteorite or $1.5 \mathrm{~m}$. The densities of Siderites are about $8000 \mathrm{~kg} / \mathrm{m}^{3}$; this is why Siderites constitute an iron of excellent quality because precisely of this significant density which they acquire while condensing under high pressures inside the heart of the parent body during its differentiation. The volume of this ellipsoid is given by the relation: $V=\frac{4}{3} \pi(0.75 \times 1.5 \times 3)$ is $14 \mathrm{~m}^{3}$.

Having got value of volume and that of the density allows the precise determination of the mass either $113,097 \mathrm{~kg}$ or 113 tonnes! We point out here that the meteorite being deeply buried and being prolonged towards the West on more than $3 \mathrm{~m}$ of distance, the dimensions used for calculations carried out above because they refer only to the visible part of this meteorite, obviously represent only the first approach in this evaluation the mass of the "two camels" is largely beyond the 113 tonnes. 113 tonnes of mass corresponds for this first evaluation, close to the double of the mass of the meteorite of Hoba in Namibia, another Siderite of a mass of 60tonnes considered so far the largest meteorite in the world: the "two camels" of Koussa in Mayo Binka in Cameroon (Plate II), is consequently, the largest meteorite in the world.

\section{Conclusions}

It is of tradition in Cameroon and beyond in central Africa to indicate the iron-bearing formations as "Itabirites"

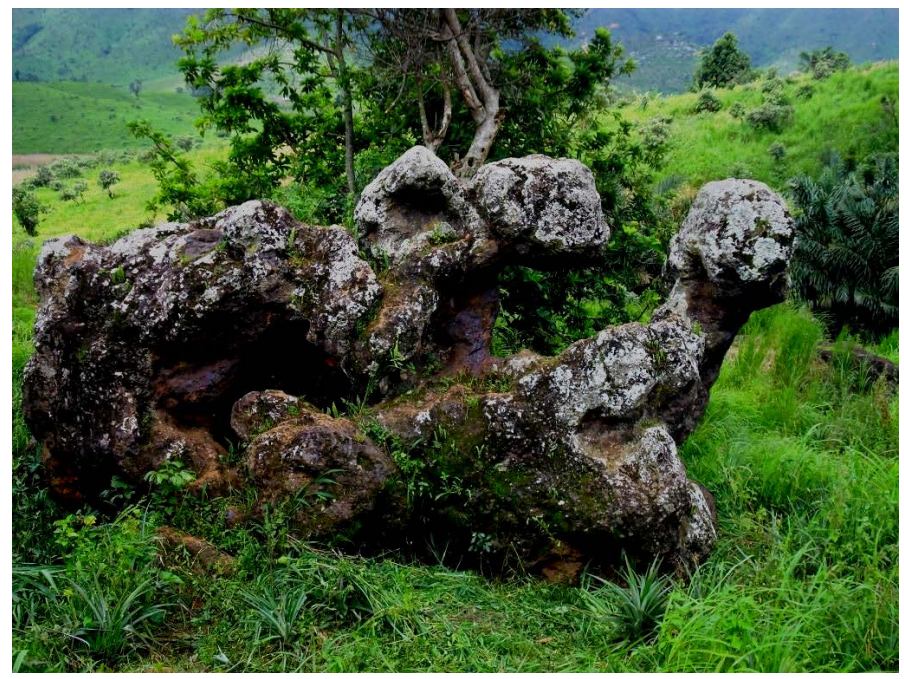

Plate II. The "two camels couple" of Koussa; here the south view showing the characteristic attitude at rest of such biologic animals. The siderite lengthens along the W-E direction (the East is on the right). 

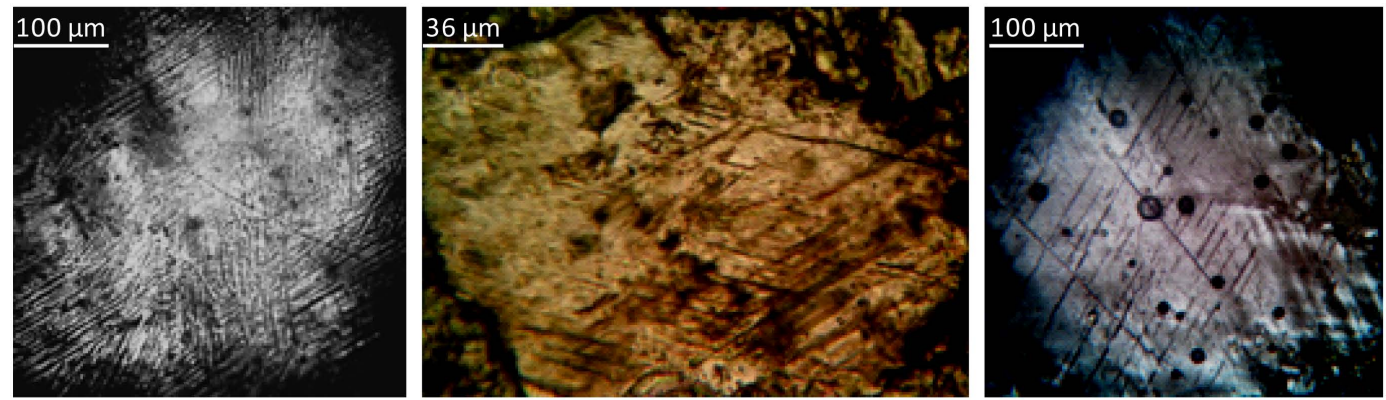

Plate III. Shocked minerals; on the left, a shocked quartz from Precambrian granites of Mayo Binka. On the top right, a shocked quartz from breccias in Ndikinimeki. Besides on the right and below, a shocked plagioclases from the Ntem Complex in Sangmelima.

or "BIF". This designation because of the younger age and the metamorphic nature of the designated formations eludes as quickly as easily the very old sedimentary context of "BIF" installation on Earth. And this designation also causes serious confusions and major contradictions to national geological maps! Are the geographical sites of these "Itabirites" in Cameroon sedimentary, metamorphic or magmatic in nature? Are the bearing magnetites quarzites of Ngovayang or those of Ndikinimeki and elsewhere in Cameroon of 2billions years in age the real minimum age of true Itabirites on Earth?

Taking into account the meteoritic character of the iron of the Gulf of Guinea, then the geomorphology and the high recurrence of the crystalline basement in shocked minerals (Plate III), mainly of quartz [17]-[27], make it possible to foresee an arrival from space, of immense metallic blocks whose collision with the target crystalline basement succeeds in explaining more simply the distribution of the iron ores not only inside the individual territories, but also beyond. The emblematical "two camels" of Koussa in Mayo Binka (Plate II), a siderite of the Hexaedrites class, of a minimal mass of 113 tonnes, from now on the largest meteorite in the world, is the concrete and irrefutable proof of such arrivals.

\section{References}

[1] Alvarez, L.W., Alvarez, W., Asaro, F. and Michel, H.V. (1980) Extraterrestrial Cause for the Cretaceous-Tertiary Extinction. Science, 208, 1095-1108. http://dx.doi.org/10.1126/science.208.4448.1095

[2] Govindaraju, K. and Mevelle, G. (1987) Fully Automated Dissolution and Separation Methods for Inductively Coupled Plasma Atomic Emission Spectrometry Rock Analysis. Application to the Determination of Rare Earth Elements. Journal of Analytical Atomic Spectrometry, 2, 615-621. http://dx.doi.org/10.1039/ja9870200615

[3] Carion, A. (1993) Les météorites et leurs impacts. Armand Colin, France, 154 p.

[4] Allègre, C. (1982) Les premiers jours de la Terre. In Le système solaire, Belin, 284 p.

[5] Combes, M.-A. (2007) La Terre bombardée. 442 p. http://www.astrosurf.com/macombes/La\%20Terre\%20Bombardee\%202007.pdf

[6] Marcelin, M. (1996) Ciel et Astronomie. Hachette, France, 211 p.

[7] Bontognali, T.R.R., Fischer, W.W. and Föllmi, K.B. (2013) Siliciclastic Associated Banded Iron Formation from the 3.2 Ga Moodies Group Barberton Greenstone Belt, South Africa. Precambrian Research, 226, 116-124. http://dx.doi.org/10.1016/j.precamres.2012.12.003

[8] Cannon, W.F., LaBerge, G.L., Klasner, J.S. and Schulz, K.J. (2007) The Gogebic Iron Range-A Sample of the Northern Margin of the Penokean Fold and Thrust Belt: U.S. Geological Survey Professional Paper 1730, 44 p.

[9] Vorontsov-Vel'yaminov, B.A. (1985) Essays about the Universe. Mir, Moscow, 326 p.

[10] Greeley, R. (1987) Planetary Landscapes. Allen \& Unwin, UK, 275 p.

[11] Greeley, R., Flink, J., Gault, D.E., Snyder, D.B., Guest, J.E. and Schultz, P.H. (1980) Impact Cratreing in Viscous Targets: Laboratory Experiments. Proceedings of the 11th Lunar and Planetary Science Conference, Houston, 17-21 March 1980, 2075-2097.

[12] Reeves, H. (1980) Patience dans l’azur. L’évolution cosmique. Seuil, 251 p.

[13] Reeves, H. (2008) Poussières d'étoiles. Seuil, 448 p.

[14] Krauskopf, K.B. and Beiser, A. (2006) The Physical Universe. McGraw-Hill, Boston, 706 p. 
[15] Melosh, H.J. (1989) Impact Cratering: A Geologic Process. Oxford University Press, New York, 254 p.

[16] Melosh, H.J. and Collins, G.S. (2005) Meteor Crater Formed by Low Velocity Impact. Nature, 434, 157. http://dx.doi.org/10.1038/434157a

[17] Huffman, A.R. and Reimold, W.U. (1996) Experimental Constraints on Shock Induced Microstructures in Naturally Deformed Silicates. Tectonophysics, 256, 165-217. http://dx.doi.org/10.1016/0040-1951(95)00162-X

[18] French, B.M. (1998) Traces of Catastrophe: A Handbook of Shock-Metamorphic Effects in Terrestrial Meteorite Impact Structures. LPI Contribution No. 954, 111 p.

[19] Dence, M.R. (1972) The Nature and Significance of Terrestrial Impact Structures. Proceedings of the 24th International Geological Congress, Montreal, 21-30 August 1972, 77-89.

[20] Stöffler, D. and Langenhorst, F. (1994) Shock Metamorphism of Quartz in Nature and Experiment: I Basic Observation and Theory. Meteoritics, 29, 155-181. http://dx.doi.org/10.1111/j.1945-5100.1994.tb00670.x

[21] Gault, D.E., Quaide, W.L. and Oberbeck, V.R. (1968) Impact Cratering Mechanics and Structures. In: French, B.M. and Short, N.M., Eds., Shock Metamorphism of Natural Materials, Mono Book, Baltimore, 87-99.

[22] Koeberl, C. (1993) Chicxulub Crater, Yucatan: Tektites, Impact Glasses, and the Geochemistry of Target Rocks and Breccias. Geology, 21, 211-214. http://dx.doi.org/10.1130/0091-7613(1993)021<0211:CCYTIG>2.3.CO;2

[23] Koeberl, C. (1997) Impact Cratering: The Mineralogical and Geochemical Evidence. In: Johnson, K. and Campbell, J., Eds., Proceedings “The Ames Structure and Similar Structure”, Oklahoma Geological Survey, Norman, OK, 30-54.

[24] Rankine, W.J.M. (1870) On the Thermodynamic Theory of Waves of Finite Disturbance. Transactions of the Royal Society, 160, 277-288.

[25] Grieve, R.A.F., Langenhorst, F. and Stöffler, D. (1996) Shock Metamorphism of Quartz in Nature and Experiment: II Significance in Geoscience. Meteoritics \& Planetary Science, 31, 6-35. http://dx.doi.org/10.1111/j.1945-5100.1996.tb02049.x

[26] Stokes, G.G. (1848) On a Difficulty in the Theory of Sound. Philosophical Magazine, 33, 349-356.

[27] Tattevin, H. (1987) Déformation et transformation de phase induites par ondes de choc dans les silicates. Mémoires et Documents du Centre d'Etude structurale des Socles. No. 13, Université de Rennes I, Rennes, 150 p. 